\title{
PENGARUH PERSEPSI DUKUNGAN ORGANISASI, KARAKTERISTIK PEKERJAAN DAN KEPUASAN KERJA TERHADAP KOMITMEN KEORGANISASIAN KARYAWAN TRIBUN JAMBI (KOMPAS GRAMEDIA GRUP)
}

\author{
Elfira Toqwy ${ }^{1)}$, Edward $^{2)}$ \\ ${ }^{1,2)}$ Program Magister Manajemen, Pascasarjana, Universitas Jambi. \\ Email : elfiratoqwy02@gmail.com
}

\begin{abstract}
This study aims to analyze the effect of perceived organizational support, job characteristics, and job satisfaction partially and simultaneously on employee organizational commitment at Tribun Jambi. The target population for this study were the employees of Tibun Jambi with a total of 85 employees. Where the sampling technique in this study used Saturated Sampling (Census Sampling). This study uses a survey method in data collection. Then proceed with the statistical method to test the hypothesis, namely multiple linear regression (multiple regression). The results of this study indicate that perceptions of organizational support, job characteristics, and job satisfaction have a positive and significant effect on employee organizational commitment either partially or simultaneously. Where from the tests carried out, it is known that the job characteristics variable has a more dominant influence than the perception of organizational support and job satisfaction.
\end{abstract}

Keywords: Perceived Organizational Support, Job Characteristics, Job Satisfaction, and Employee Organizational Commitment

\begin{abstract}
Abstrak
Penelitian ini bertujuan menganalisis pengaruh persepsi dukungan organisasi, karakteristik pekerjaan, dan kepuasan kerja secara parsial dan simultan terhadap komitmen keorganisasian karyawan pada Tribun Jambi. Populasi target untuk penelitian ini adalah karyawan Tibun Jambi dengan jumlah 70 orang karyawan. Dimana teknik penarikan sampel dalam penelitian ini menggunakan Sampling Jenuh (Sampling Sensus). Penelitian ini menggunakan metode survey dalam pengumpulan datanya. Kemudian dilanjutkan dengan metode statistik untuk menguji hipotesis yaitu dengan regresi linear berganda (multiple regression). Hasil penelitian ini menunjukkan bahwa bahwa persepsi dukungan organisasi, karakteristik pekerjaan, dan kepuasan kerja memiliki pengaruh positif dan signifikan terhadap komitmen keorganisasian karyawan baik secara parsial maupun secara simultan. Dimana dari pengujian yang dilakukan diketahui bahwa variabel karakteristik pekerjaan memiliki pengaruh yang lebih dominan dibandingkan dengan persepsi dukungan organisasi dan kepuasan kerja.
\end{abstract}

Kata Kunci: Persepsi Dukungan Organisasi, Karakteristik Pekerjaan, Kepuasan Kerja, dan Komitmen Keorganisasian Karyawan.

Correspondence email: elfiratoqwy02@gmail.com 


\section{PENDAHULUAN}

Tribun Jambi adalah sebuah surat kabar harian yang terbit di Jambi, Indonesia. Surat kabar ini termasuk dalam grup Kompas Gramedia. Kantor pusatnya terletak di kota Jambi. Koran ini pertama kali terbit tahun 2009. Melalui Tribun Jambi diharapkan kota jambi dengan motto "Tanah Pilih Pesako Betuah" secara filosofi mengandung pengertian bahwa Kota Jambi sebagai pusat pemerintahan kota sekaligus sebagai pusat sosial, ekonomi, kebudayaan, mencerminkan jiwa masyarakatnya sebagai duta kesatuan baik individu, keluarga, dan kelompok maupun secara institusional yang lebih luas; berpegang teguh dan terikat pada nilai-nilai adat istiadat dan hukum adat serta peraturan perundang-undangan yang berlaku. Tribun Jambi hadir dalam upaya memberikan informasi yang lengkap, akurat, dan memberikan warna berbeda kepada masyarakat Kota Jambi.

Sebagaimana perusahaan pada umumnya, Tribun Jambi senantiasa menginginkan untuk memiliki karyawan dengan komitmen yang tinggi. Karena dengan memiliki karyawan yang berkomitmen tinggi, akan sangat membantu sekali bagi perusahaan dalam pencapaian tujuannya tanpa banyak mengalami kendala, seperti rendahnya komitmen karyawan untuk tetap bekerja dalam jangka waktu yang ditentukan oleh perusahaan.

Komitmen karyawan merupakan salah satu kunci yang turut menentukan berhasil tidaknya suatu organisasi untuk mencapai tujuannya. Karyawan yang mempunyai komitmen pada organisasi biasanya mereka menunjukan sikap kerja yang penuh perhatian terhadap tugasnya, mereka sangat memiliki tanggung jawab untuk melaksanakan tugastugas serta sangat loyal terhadap perusahaan. Dalam komitmen terkandung keyakinan, pengikat, yang akan menimbulkan energi untuk melakukan yang terbaik. Secara nyata, komitmen berdampak kepada performansi kerja sumber daya manusia, dan pada akhirnya juga sangat berpengaruh terhadap kinerja suatu perusahaan (Purwanto \& Soliha, 2017).

Komitmen organisasional merupakan suatu keadaan dimana seorang karyawan memihak organisasi tertentu serta tujuan-tujuan dan keinginannya untuk mempertahankan keanggotaan dalam organisasi tersebut (Robbins \& Judge, 2013). Komitmen organisasional menjadi suatu hal yang penting pada zaman sekarang ini. Ketika sebuah perusahaan sangat sulit mencari karyawan yang memiliki kualifikasi yang sangat baik dalam melakukan pekerjaannya, komitmen organisasional adalah salah satu cara dalam menentukan karyawan yang memiliki kualifikasi, loyalitas dan kinerja yang baik. Dengan kata lain, komitmen organisasional dijadikan sebagai hal yang penting dalam menentukan karyawan pada level kinerja didalam suatu perusahaan.

Penelitian-penelitian dibidang komitmen organisasional telah menarik minat akademisi sejak lama dan sudah sejak lama penelitian dalam karya ilmiah maupun jurnal telah dihasilkan diantaranya yaitu penelitian yang dilakukan oleh (Ramadhani, 2018), (Purnami, 2017), (Sancaya, 2019), (Ekayanti et al., 2019), (Purwanto \& Soliha, 2017), dan (Novieka \& Prasetya, 2018). Namun dari sekian banyak penelitian yang telah dilakukan masih jarang melakukan penelitian pada perusahaan surat kabar harian, dan hal inilah membuat penulis tertarik melakukan penelitian pada surat kabar harian Tribun Jambi.

Komitmen dalam organisasi tidak terjadi begitu saja dengan sangat mudah dan cepat. Melainkan mengalami proses yang bertahap dan cukup panjang. Secara garis besar komitmen organisasi dipengaruhi oleh dua faktor yaitu faktor personal dan faktor organisasi. Faktor personal, yang salah satunya merupakan faktor kepribadian. Yang mana sebagai pondasi komitmen keorganisasian yang dimiliki oleh karyawan. Dalam hal ini dapat diimplementasikan dalam bentuk kepuasan kerja. Hal ini (Mathis \& Jackson, 2012) yang menyatakan bahwa orang yang relatif puas dengan pekerjaannya akan lebih 
berkomitmen pada organisasi dan orang-orang yang berkomitmen terhadap organisasi lebih mungkin mendapatkan kepuasan yang lebih besar.

Sedangkan faktor organisasi yaitu ciri pekerjaan, seperti identitas tugas dan kesempatan berinteraksi dengan rekan kerja dan lain sebagainya. Dalam hal ini dapat diimplementasikan dalam bentuk perceived organizational support (dukungan organisasi), dan karakteristik pekerjaan. Hal ini dikemukakan oleh (Rhoades \& Eisenberger, 2002) yang mengungkapkan bahwasanya karyawan yang merasa bahwa dirinya mendapatkan dukungan dari organisasi akan memiliki rasa kebermaknaan dalam diri karyawan tersebut. Hal inilah yang akan meningkatkan komitmen pada diri karyawan. Komitmen inilah yang pada akhirnya akan mendorong karyawan untuk berusaha membantu organisasi mencapai tujuannya. Sedangkan karakteristik pekerjaan di kemukakan oleh Elanain dalam (Ekayanti et al., 2019) yang menegaskan bahwa untuk meningkatkan komitmen karyawan serta untuk mengurangi intensi turnover, maka perusahaan perlu memperhatikan faktor karakteristik pekerjaan.

Berangkat dari fenomena yang telah dikemukakan di atas, maka menimbulkan ketertarikan penulis untuk mengangkat topik ini menjadi suatu kajian empirik dalam bentuk Tesis dengan judul "Pengaruh Persepsi Dukungan organisasi, Karakteristik Individu, dan Kepuasan Kerja Terhadap Komitmen Keorganisasian Karyawan Tribun Jambi (Kompas Gramedia Grup)".

\section{Tujuan Penelitian}

Berdasarkan permasalahan yang ada, adapun tujuan yang dingin dicapai dalam peneltian ini adalah untuk mendeskripsikan gambaran persepsi dukungan organisasi, karakteristik pekerjaan, kepuasan kerja, dan komitmen keorganisasian karyawan pada Tribun Jambi; serta untuk menganalisis pengaruh persepsi dukungan organisasi, karakteristik pekerjaan, dan kepuasan kerja baik secara parsial maupun secara simultan berpengaruh terhadap komitmen keorganisasian karyawan.

\section{TINJAUAN PUSTAKA}

\section{Komitmen Keorganisasian Karyawan}

Komitmen adalah perjanjian untuk melakukan sesuatu bagi diri sendiri, individu lain, kelompok, atau organisasi (Kreitner \& Kinicki, 2014). Lebih lanjut (Kreitner \& Kinicki, 2014) menjelaskan bahwa komitmen keorganisasian adalah cerminan dimana seorang karyawan dalam mengenali organisasi dan terikat kepada tujuan-tujuannya. Ini adalah sikap kerja yang penting karena orang-orang memiliki komitmen diharapkan dapat menunjukkan ketersediaannya untuk bekerja lebih keras demi mencapai tujuan organisasi dan memiliki hasrat yang lebih besar untuk tetap bekerja di suatu perusahaan.

Menurut (Robbins \& Judge, 2013) mendefinisikan komitmen keorganisasian sebagai suatu keadaan dimana seseorang karyawan memihak organisasi tertentu serta tujuan dan keinginannya untuk mempertahankan keanggotaan dalam organisasi tersebut. Komitmen keorganisasian adalah sikap yang mencerminkan sejauh mana seseorang individu mengenal dan terikat pada organisasinya. Seseorang individu yang memiliki komitmen tinggi kemungkinan akan melihat dirinya sebagai anggota sejati organisasi (Luthans, 2006).

Kreitner dan Kinicki mengemukakan adanya tiga bentuk komitmen keorganisasian (Kreitner \& Kinicki, 2014), yaitu: 1) Komitmen berkesinambungan (continuance commitment), yaitu komitmen yang berhubungan dengan dedikasi anggota dalam melangsungkan kehidupan organisasi dan menghasilkan orang yang mau berkorban dan 
berinvestasi pada organisasi; 2) Komitmen terpadu (cohesion commitment), yaitu komitmen anggota terhadap organisasi sebagai akibat adanya hubungan sosial dengan anggota lain di dalam organisasi. Ini terjadi karena karyawan percaya bahwa norma-norma yang dianut organisasi merupakan norma-norma yang bermanfaat; dan 3) Komitmen terkontrol (control commitment), yaitu komitmen anggota pada norma organisasi yang memberikan perilaku ke arah yang diinginkannya. Norma-norma yang dimiliki organisasi sesuai dan mampu memberikan sumbangan terhadap perilaku yang diinginkannya.

\section{Perceived Organizational Support (Persepsi Dukungan Organisasi)}

Persepsi dukungan organisasi didefinisikan sebagai tingkat di mana karyawan percaya bahwa organisasi mereka menghargai kontribusi dan kepedulian mereka terhadap kesejahteraan mereka (Afzali et al., 2014). Kemudian menurut Guan et al dalam (Islam et al., 2015) perceived organizational support atau dukungan organisasi yang dirasakan adalah tingkat di mana karyawan percaya bahwa organisasi kerja mereka menghargai kontribusi dan kepedulian mereka terhadap kesejahteraan mereka.

Menurut persepsi dukungan organisasi yang dirasakan adalah tingkat di mana karyawan yakin organisasi menghargai kontribusi mereka dan peduli dengan kesejahteraan mereka. persepsi dukungan organisasi dapat juga dipandang sebagai komitmen organisasi pada karyawan (Rhoades \& Eisenberger, 2002). Apabila pihak organisasi secara umum menghargai dedikasi dan loyalitas karyawan sebagai bentuk komitmen karyawan terhadap organisasi, maka para karyawan secara umum juga memperhatikan bagaimana komitmen yang dimiliki organisasi terhadap mereka. Penghargaan yang diberikan oleh organisasi dapat dianggap memberikan keuntungan bagi karyawan, seperti adanya perasaan diterima dan diakui, memperoleh gaji dan promosi, mendapatkan berbagai akses informasi, serta beberapa bentuk bantuan lain yang dibutuhkan karyawan untuk dapat menjalankan pekerjaannya secara efektif. Terdapatnya norma timbal balik ini menyebabkan karyawan dan organisasi harus saling memperhatikan beberapa tujuan yang ada dalam hubungan kerja tersebut (Rhoades \& Eisenberger, 2002).

Menurut (Robbins \& Judge, 2013) persepsi dukungan organisasi mengacu pada persepsi karyawan mengenai sejauh mana organisasi menghargai kontribusi dan kepedulian mereka terhadap kesejahteraan mereka. Konsep persepsi dukungan organisasi mengusulkan bahwa karyawan mempersonifikasikan organisasi tempat mereka bekerja dan membentuk kepercayaan global tentang sejauh mana organisasi menghargai kontribusi dan kepedulian mereka terhadap kesejahteraan mereka.

Menurut (Rhoades \& Eisenberger, 2002), terdapat tiga bentuk umum perlakuan dari organisasi yang dianggap baik dan akan dapat meningkatkan dukungan organisasi yang dirasakan karyawan, yaitu: 1) Keadilan (Fairness); 2) Dukungan Atasan (Supervisor Support); dan 3) Imbalan-imbalan dari porganisasi dan kondisi kerja (Organizational Rewards and Job Condition).

\section{Karakteristik Pekerjaan}

Karakteristik pekerjaan merupakan sifat dari tugas yang meliputi tanggung jawab, macam tugas dan tingkat kepuasan yang diperoleh dari pekerjaan itu sendiri. Menurut Hackman dan Oldham dalam (Robbins \& Judge, 2013), karakteristik pekerjaan adalah upaya mengidentifikasikan karakteristik tugas dari pekerjaan, bagaimana karakteristik itu digabung untuk membentuk pekerjaan yang berbeda dan hubungannya dengan motivasi, kepuasan kerja dan kinerja karyawan. 
Stoner and Wankel dalam (Ekayanti et al., 2019) mengemukakan banwa karakteristik pekerjaan adalah atribut tugas karyawan dan meliputi sejumlah tanggungjawab, berbagai tugas, dan sejauh mana pekerjaan itu memiliki karakteristik yang dapat membuat karyawan merasakan kepuasan. Sedangkan menurut (Panggabean, 2011) mengatakan bahwa karakteristik pekerjaan berkaitan dengan pekerjaan itu sendiri ia berkaitan dengan cara bagaimana karyawan menilai tugas-tugas yang ada dalam pekerjaannya. Secara pragmatis jawaban dari pertanyaan tentang karakteristik pekerjaan dapat digunakan melalui model karakteristik pekerjaan.

Model karakteristik pekerjaan (job characteristic models) merupakan suatu pendekatan terhadap pemerkayaan pekerjaan (job enrichment). Program pemerkayaan pekerjaan berusaha merancang pekerjaan dengan cara membantu para pemangku jabatan memuaskan kebutuhan mereka akan pertumbuhan, pengakuan, dan tanggung jawab. Pemerkayaan pekerjaan menambahkan sumber kepuasan kepada pekerjaan. Metode ini meningkatkan tanggung jawab, otonomi, dan kendali (Henry, 2003).

Dalam model karakteristik pekerjaan Hackman dan Oldham dalam (Robbins \& Judge, 2013) terdapat lima karakteristik inti yang mempengaruhi critical psychological states, yaitu keragaman keterampilan, identitas tugas, pentingnya tugas, otonomi dan umpan balik pekerjaan. Kelima dimensi dari karakteristik kerja tersebut menciptakan tingkat reaksi psikologis seseorang tentang makna, tanggung jawab serta pengetahuan yang dihasilkan dari pekerjaan tersebut yang pada akhirnya berdampak pada motivasi, kinerja, dan kepuasan kerja karyawan serta tingkat kemangkiran dan tingkat keluar masuknya karyawan.

\section{Kepuasan Kerja}

Kepuasan kerja adalah sikap emosional yang menyenangkan dan mencintai pekerjaannya. Sikap ini dicerminkan oleh moral kerja, kedisiplinan dan prestasi kerja. Kepuasan kerja dinikmati dalam pekerjaan, luar pekerjaan, dan kombinasi dalam dan luar pekerjaan (Hasibuan, 2011). Menurut (Robbins \& Judge, 2013) kepuasan kerja merupakan suatu sikap umum terhadap pekerjaan seseorang, selisih antara banyaknya ganjaran yang diterima seorang karyawan dan banyaknya yang mereka yakini apa yang seharusnya mereka terima.

Selain itu (rivai dan sagala, 2011) mendefinisikan kepuasan kerja merupakan evaluasi yang menggambarkan seseorang atas perasaan sikapnya senang atau tidak senang, puas atau tidak puas dalam bekerja. Lebih lanjut (Handoko, 2011) mengemukakan bahwa kepuasan kerja adalah keadaan emosional yang menyenangkan atau tidak menyenangkan dengan mana para karyawan memandang pekerjaan mereka. Kepuasan kerja mencerminkan perasaan seseorang terhadap pekerjaannya. Kepuasan kerja terkait dengan penilaian tentang karakteristik pekerjaan, lingkungan, dan pengalaman emosional di tempat kerja. Karyawan yang puas mempunyai penilaian yang baik tentang pekerjaan mereka, berdasarkan pengamatan dan pengalaman mereka. Kepuasan kerja merupakan sekumpulan sikap tentang aspek-aspek yang berbeda dari tugas dan konteks pekerjaan.

Kepuasan kerja akan mendorong karyawan untuk berprestasi lebih baik. Prestasi yang lebih baik akan menimbulkan imbalan ekonomi dan psikologi yang lebih tinggi. Apabila imbalan tersebut dipandang pantas dan adil maka timbul kepuasan yang lebih besar karena karyawan merasa bahwa mereka menerima imbalan sesuai dengan prestasinya. Sebaliknya apabila imbalan dipandang tidak sesuai dengan tingkat prestasi maka cenderung timbul keptidakpastian. Kepuasan kerja tergantung kesesuaian atau keseimbangan antara yang diharapkan dengan kenyataan. Menurut (Robbins \& Judge, 
2013) faktor-faktor yang menentukan kepuasan kerja adalah: 1) Kerja yang secara mental menantang; 2) Ganjaran yang pantas; 3) Kondisi kerja yang mendukung; 4) Rekan kerja yang mendukung; dan 5) Kesesuaian antara kepribadian pekerjaan.

\section{Kerangka Berpikir}

Berdasarkan pemaparan teori, kajian dari penelitian terdahulu di atas dan hubungan antar variabel penelitian, maka untuk menjawab permasalahan penelitian dibentuk kerangka pemikiran seperti terlihat pada gambar berikut.

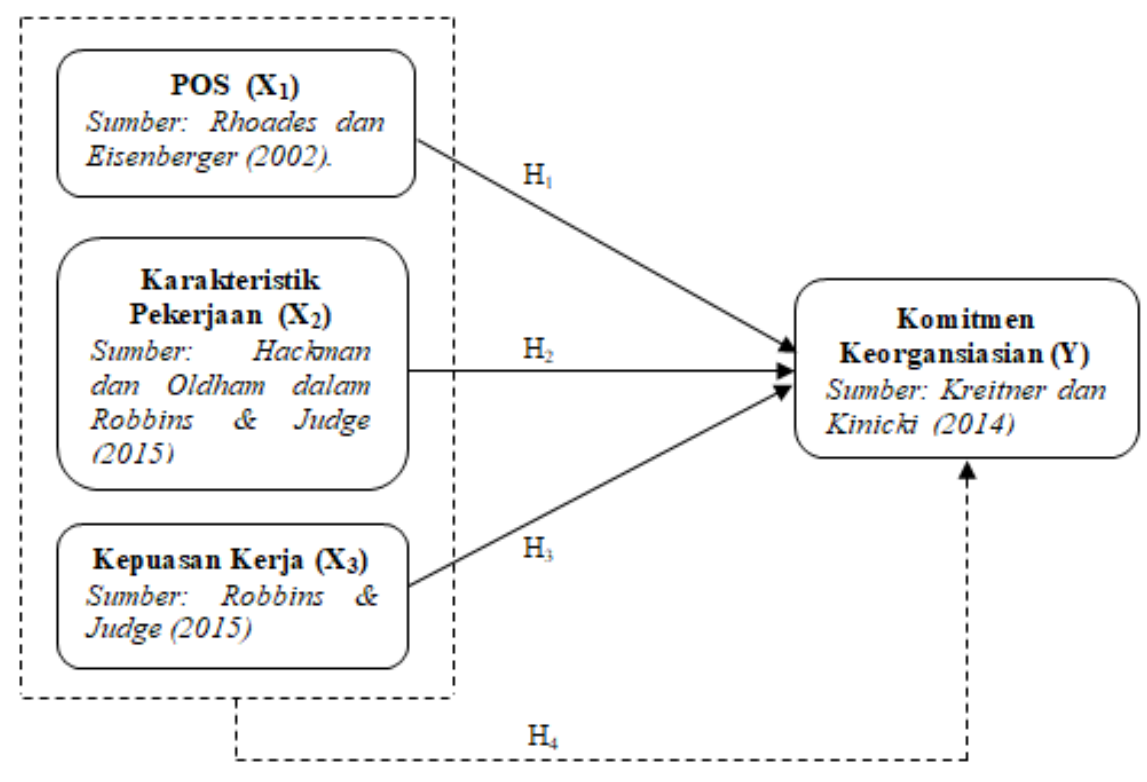

Gambar 1. Kerangka Berpikir

\section{Hipotesis}

Berdasarkan telaah teori dan beberapa asumsi yang telah dikemukakan terdahulu, maka hipotesis penelitian adalah Perceived Organizational Support, karakteristik pekerjaan, dan kepuasan kerja berpengaruh signfikan terhadap komitmen keorganisasian karyawan baik secara simultan maupun parsial.

\section{METODE PENELITIAN}

Populasi target untuk penelitian ini adalah karyawan Tibun Jambi dengan jumlah 85 orang karyawan. Teknik pengambilan sampel pada penelitian ini menggunakan teknik probability sampling, yaitu teknik pengambilan sampel yang memberikan peluang yang sama bagi setiap unsur (anggota) populasi untuk dipilih sebagai anggota sampel. Untuk menentukan jumlah sampel yang dipilih digunakan rumus slovin dengan nilai $\mathrm{e}=5 \%$ sehingga diperoleh sampel sebesar 70 .

Teknik analisis data yang penulis gunakan dalam penelitian ini yakni menggunakan persamaan regresi linear berganda (multiple regression) dengan alat bantu yang di gunakan yaitu SPSS for Windows versi 21.0. Namun sebelumnya penulis terlebih dahulu melakukan uji kualitas data, uji asumsi klasik (Uji Normalitas, Uji Multikolinearitas, dan Uji Heterokedastisitas). Dan kemudian dilanjutkan dengan persamaan regresi, koefisien determinasi, uji parsial dan uji simultan. 


\section{HASIL DAN PEMBAHASAN}

\section{Analisis Deskriptif Profil Responden}

Profil responden penelitian dibagi menjadi 4 jenis, yaitu berdasarkan jenis kelamin, usia, tingkat pendidikan, dan masa kerja. Responden berjenis kelamin Laki-laki yaitu sebanyak 78,6 persen, dan wanita sebanyak 21,4 persen. Selanjutnya berdasarkan kelompok usia, kelompok atas usia 18 - 25 tahun sebanyak 18,6 persen, kemudian untuk kelompok usia 26 - 35 tahun sebanyak 41,4 persen, kelompok usia 36 - 45 tahun sebanyak 34,3 persen, dan untuk kelompok usia 46 - 55 tahun sebanyak 5,7 persen. Pada karateristik tingkat pendidikan responden, untuk SMA/SMK sebanyak 20 persen, Diploma sebanyak 27,1 persen, Strata Satu (S1) sebanyak 47,1 persen, dan untuk Strata Dua (S2) sebanyak 5,7 persen. Pada karateristik berdasarkan masa kerja, untuk $1-2$ tahun sebanyak 7,1 persen, 3 - 4 sebanyak 12,9 persen, 5 - 6 sebanyak 30 persen, $7-8$ tahun sebanyak 27,1 persen, dan untuk $>8$ tahun sebanyak 22,9 persen.

\section{Hasil Deskripsi Jawaban Responden Atas Variabel Penelitian}

a. Deskripsi Data Variabel Komitmen Keorganisasian (Y).

Dari lima belas pernyataan yang diajukan untuk variable komitmen organisasi (Y) diperoleh skor rata-rata sebesar 239,1. Apabila dilihat pada Kriteria presentase skor responden terhadap skor ideal, variabel komitmen keorgansiasian karyawan termasuk pada range 238 - 293 berada pada kriteria tinggi.

\section{b. Deskripsi Data Variabel Persepsi Dukungan Organisasi $\left(\mathbf{X}_{1}\right)$}

Dari lima belas pernyataan yang diajukan untuk variable persepsi dukungan organisasi $\left(\mathrm{X}_{1}\right)$ diperoleh skor rata-rata sebesar 231,5. Apabila dilihat pada Kriteria presentase skor responden terhadap skor ideal, variabel persepsi dukungan organisasi termasuk pada range 182 - 237 berada pada kriteria cukup baik. Yang menjelaskan bahwa persepsi karyawan terhadap dukungan Tribun Jambi (Kompas Gramedia Grup) di persepsikan cukup baik oleh karyawan.

\section{c. Deskripsi Data Variabel Karakteristik Pekerjaan $\left(\mathbf{X}_{2}\right)$}

Dari sepuluh pernyataan yang diajukan untuk Variabel karakteristik pekerjaan $\left(\mathrm{X}_{2}\right)$ diperoleh skor rata-rata sebesar 236,6. Apabila dilihat pada Kriteria presentase skor responden terhadap skor ideal, variabel karakteristik pekerjaan termasuk pada range 182 237 berada pada kriteria cukup baik. Yang menjelaskan bahwasanya karakteritik pekerjaan karyawan pada Tribun Jambi (Kompas Gramedia Grup) sudah cukup sesuai dengan pekerjaan yang dilaksanakannya.

\section{d. Deskripsi Data Variabel Kepuasan Kerja $\left(X_{3}\right)$}

Dari delapan pernyataan untuk variabel kepuasan kerja $\left(\mathrm{X}_{3}\right)$ diperoleh skor rata-rata sebesar 238,6. Apabila dilihat pada kriteria presentase skor responden terhadap skor ideal, variabel kepuasan kerja termasuk pada range 238 - 293 berada pada kriteria puas. Yang menjelaskan bahwa karyawan cukup puas bekerja pada Tribun Jambi (Kompas Gramedia Grup).

\section{Hasil Uji Statistik}

Hasil uji validitas dari seluruh variabel penelitian menunjukkan kondisi valid, dengan $r_{\text {tabel }}(0,235)$. Sama dengan itu, uji reliabilitas menggunakan Cronbach's Alpha lebih besar dari 0,6. Dengan demikian maka dapat dilanjutkan uji statistik untuk kepentingan pengujian hipotesis. 


\section{Jurnal Manajemen Terapan dan Keuangan (Mankeu) Vol. 10 No. 01, April 2021 P-ISSN: 2252-8636, E-ISSN: 2685-9424}

Kemudian dari hasil uji asumsi klasik yang dilakukan diperoleh hasil bahwa data dalam penelitian ini berdistribusi normal, hal ini dibuktikan dari nilai Asymp. Sig. 2-tailed untuk keempat variable memiliki signfikan lebih besar dari 0,05 , yaitu untuk variable persepsi dukungan organisasi $(0,165>0,05)$, karakteristik pekerjaan $(0,105>0,05)$, kepuasan kerja $(0,122>0,05)$, dan komitmen keorganisasian $(0,177>0,05)$, sehingga dapat disimpulkan bahwa data dalam penelitian ini berdistribusi normal.

Selanjutnya dari uji multikolinearitas yang dilakukan diperoleh Tolerance lebih dari 0.10 , yaitu $(0,380 ; 0,538$; dan 0,465$)$ yang berarti tidak ada korelasi antar variabel independent. Selain itu pula hasil perhitungan nilai Variance Inflation Factor (VIF) juga menunjukan hal yang sama tidak ada satu variabel independent yang memiliki nilai VIF lebih dari 10, melainkan nilai VIFnya untuk ketiga variable di bawah 10 yaitu $(2,632$; 1,859; dan 2,150). Berdasarkan hasil tersebut maka dapat disimpulkan bahwa tidak terjadi multikolinearitas antar variabel Independent dalam model regresi.

Dan pengujian uji asumsi klasik yang terakhir melalui uji heterokedastisitas, diperoleh hasil bahwa titik-titik scatterplots menyebar secara acak serta tersebar baik diatas maupun dibawah angka 0 pada sumbu Y. hal ini dapat disimpulkan bahwa tidak terjadi heterokedastisitas pada model regresi, sehingga model regresi layak dipakai untuk memprediksi penggunaan jasa akomodasi berdasarkan masukan variabel independent.

Setelah terbukti bahwa model persamaan yang diajukan dalam penelitian ini telah memenuhi persyaratan asumsi klasik sehingga model persamaan dalam penelitian ini sudah dianggap baik. Analisis regresi digunakan untuk menguji hipotesis tentang pengaruh secara parsial variabel bebas terhadap variabel terikat. Berdasarkan estimasi regresi berganda dengan program SPSS 21.0 diperoleh hasil seperti Tabel berikut :

Tabel 1. Hasil Analisis Regresi Linier Berganda

\begin{tabular}{llcc}
\hline No. & \multicolumn{1}{c}{ Ukuran Statistik } & Nilai Hitung dan Koefisien regressi & $\mathrm{P}_{\text {value }}$ \\
\hline 1 & Uji F & 31,598 & $0.000^{* *}$ \\
& Uji t (koefisien) & 0,288 & \\
& $\bullet P O S$ & 0,495 & $0,028^{*}$ \\
& $\bullet$ Karakteeristik Pekerjaan & 0,301 & $0,004^{* *}$ \\
& • Kepuasan Kerja & 0,590 & $0,021^{*}$ \\
2 & Kofisien Determinasi $\mathrm{R}^{2}$ & & \\
\hline
\end{tabular}

Sumber. Hasil olahan data primer dengan SPSS, 2020

Ket. *" highly dignificant

Secara statistik diperoleh persamaan regresi sebagai berikut.

$\mathrm{Y}=\mathrm{a}+\mathrm{b}_{1} \mathrm{X}_{1}+\mathrm{b}_{2} \mathrm{X}_{2}+\mathrm{b}_{3} \mathrm{X}_{3}+\mathrm{e}$

$\mathrm{Y}=7,777+0,288 \cdot \mathrm{X}_{1}+0,495 \cdot \mathrm{X}_{2}+0,301 \cdot \mathrm{X}_{3}+\mathrm{e}$

Tujuan pertama dalam penelitian ini adalah untuk analisis pengaruh persepsi dukungan organisasi terhadap komitmen keorganisasian karyawan, dari pengujian hipotesis yang dilakukan diperoleh nilai t hitung sebesar 2,242, dengan nilai signifikansi sebesar 0,028, dikarenakan angka taraf signifikansi $<0,05(0,028<0,05)$ maka dapat disimpulkan bahwa persepsi dukungan organisasi berpengaruh signifikan terhadap komitmen keorganisasian karyawan pada Tribun Jambi (Kompas Gramedia Grup). Artinya terdapat hubungan linier antara persepsi dukungan organisasi dengan komitmen keorganisasian Tribun Jambi (Kompas Gramedia Grup). 
Hasil penelitian ini sejalan dengan penelitian yang dilakukan oleh (Ramadhani, 2018), (Susmiati dan Sudarma, 2015), (Purnami, 2017), (Nazir \& Islam, 2017), (Islam et al., 2015) dan (Sharma \& Dhar, 2016) yang menyatakan bahwa persepsi dukungan organisasi memiliki hubungan yang positif terhadap komitmen keorganisasian, yang mengindikasikan bahwa persepsi dukungan organisasi dapat menanamkan rasa memiliki terhadap suatu organisasi. Ini menunjukan bahwa semakin banyaknya dukungan organisasi akan semakin menumbuhkan keterikatan emosional karyawan terhadap organisasi, begitu pula sebaliknya.

Kemudian (Ramadhani, 2018) dalam penelitiannya juga mengemukakan semakin positif persepsi karyawan pada organisasi, maka akan membuat karyawan ingin tetap tinggal atau mempertahankan pekerjaannya pada organisasi. Selain itu (Rhoades \& Eisenberger, 2002) juga mengemukakan apabila organisasi dapat menghargai dedikasi dan loyalitas karyawan sebagai bentuk komitmen karyawan terhadap organisasi, maka karyawan secara umum juga akan memperhatikan bagaimana komitmen yang dimiliki organisasi terhadap mereka.

Tujuan kedua dalam penelitian ini adalah untuk analisis pengaruh karakteristik pekerjaan terhadap komitmen keorganisasian karyawan, dari pengujian hipotesis yang dilakukan diperoleh nilai t hitung sebesar 2,942, dengan nilai signifikansi sebesar 0,004, dikarenakan angka taraf signifikansi $<0,05(0,004<0,05)$ maka dapat disimpulkan bahwa karakteristik pekerjaan berpengaruh signifikan terhadap komitmen keorganisasian karyawan pada Tribun Jambi (Kompas Gramedia Grup). Artinya terdapat hubungan linier antara karakteristik pekerjaan dengan komitmen keorganisasian Tribun Jambi (Kompas Gramedia Grup).

Hasil penelitian ini sejalan dengan penelitian yang dilakukan oleh (Martono et al., 2017), (Ekayanti et al., 2019), dan (Pratama et al., 2016) dimana hasil penelitiannya mengemukakan bahwa secara siginifikan karakteristik pekerjaan berpengaruh signifikan terhadap komitmen keorganisasian. Selain itu studi dari Udo et al yang dilakukan pada manajer pabrik manufaktur di USA, menggambarkan bahwa intensi turnover antara manajer pabrik adalah hasil keterkaitan yang kompleks antar stesor peran (role stressor), karakteristik pekerjaan, keterlibatan kerja, kepuasan kerja dan komitmen keorganisasian (Ekayanti et al., 2019). Lebih lanjut Elanain dalam (Ekayanti et al., 2019) yang menegaskan bahwa untuk meningkatkan komitmen karyawan serta untuk mengurangi intensi turnover, maka perusahaan perlu memperhatikan faktor karakteristik pekerjaan.

Karakteristik pekerjaan merupakan salah satu faktor yang dapat mempengaruhi komitmen keorganisasian karyawan. Karakteristik pekerjaan menetukan kesesuaian orang dengan suatu bidang pekerjaan tertentu dan memungkinkan seseorang untuk lebih berhasil dalam bidang yang di tekuninya. Dengan pemahaman terhadap karakteristik pekerjaan di harapkan karyawan tersebut akan semakin berorientasi di bidang pekerjaannya. Karyawan akan menekuni pekerjaan dengan konsentrasi dan tanggung jawab yang di sertai perasaan senang sampai di peroleh hasil yang memuaskan. Jika 


\section{Jurnal Manajemen Terapan dan Keuangan (Mankeu) Vol. 10 No. 01, April 2021 P-ISSN: 2252-8636, E-ISSN: 2685-9424}

seorang karyawan memiliki karakteristik yang sesuai dengan pekerjaannya komitmen karyawan pada organisasinya akan semakin meningkat pula (Pratama et al., 2016).

Tujuan ketiga dalam penelitian ini adalah untuk analisis pengaruh kepuasan kerja terhadap komitmen keorganisasian karyawan, dari pengujian hipotesis yang dilakukan diperoleh nilai t hitung sebesar 2,361, dengan nilai signifikansi sebesar 0,021, dikarenakan angka taraf signifikansi $<0,05(0,021<0,05)$ maka dapat disimpulkan bahwa kepuasan kerja berpengaruh signifikan terhadap komitmen keorganisasian karyawan pada Tribun Jambi (Kompas Gramedia Grup). Artinya terdapat hubungan linier antara kepuasan kerja dengan komitmen keorganisasian Tribun Jambi (Kompas Gramedia Grup).

Hasil penelitian ini sejalan dengan penelitian yang dilakukan oleh (Martono et al., 2017), (Pratama et al., 2016), dan (Novieka \& Prasetya, 2018) yang mengemukakan bahwa kepuasan kerja kerja memiliki hubungan yang positif terhadap komitmen keorganisasian, yang mengindikasikan bahwa jika seorang karyawan telah merasa puas dengan pekerjaan yang dilaksanakan, maka akan lebih berkomitmen pada organisasi.

Kepuasan kerja merupakan salah satu bentuk perasaan seseorang terhadap pekerjaannya, situasi kerja dan hubungan dengan rekan kerja. Oleh karena itu kepuasan kerja merupakan sesuatu yang penting untuk dimiliki seseorang karyawan, dalam berinteraksi dengan lingkungan kerjanya sehingga tanggung jawab yang diberikan oleh perusahaan dapat dilaksanakan dengan baik sesuai dengan tujuan perusahaan. Kepuasan kerja dianggap penting dalam lingkup organisasi karena memiliki pengaruh yang besar terhadap komitmen keorganisasian, hal ini dikemukan oleh (Mathis \& Jackson, 2012) yang menyatakan bahwa orang yang relatif puas dengan pekerjaannya akan lebih berkomitmen pada organisasi.

Tujuan keempat dalam penelitian ini adalah untuk analisis persepsi dukungan organisasi, karakteristik pekerjaan, dan kepuasan kerja secara simultan terhadap komitmen organisasi. Dari pengujian hipotesis yang dilakukan diperoleh nilai $F_{\text {hitung }}$ sebesar 31,598 dengan tingkat probabilitas $p$-value sebesar 0,000, dikarenakan angka taraf signifikansi jauh lebih $<0,05(0,000<0,05)$ oleh karena itu $\mathrm{H}_{0}$ ditolak dan $\mathrm{H}_{1}$ diterima, sehingga dapat disimpulkan bahwa hipotesis nol $\left(\mathrm{H}_{0}\right)$ ditolak dan hipotesis alternatif $\left(\mathrm{H}_{1}\right)$ diterima artinya hal ini membuktikan variabel persepsi dukungan organisasi, karakteristik pekerjaan, dan kepuasan kerja secara bersama-sama berpengaruh secara signifikan terhadap komitmen keorganisasian karyawan. Dimana besarnya sumbangan pengaruh variabel persepsi dukungan organisasi, karakteristik pekerjaan, dan kepuasan kerja terhadap komitmen keorganisasian karyawan sebesar 57,1\%, sedangkan sisanya sebesar 42,9\% dipengaruhi oleh variabel lain yang tidak diungkap dalam penelitian ini.

Komitmen organisasional merupakan suatu keadaan dimana seorang karyawan memihak organisasi tertentu serta tujuan-tujuan dan keinginannya untuk mempertahankan keanggotaan dalam organisasi tersebut (Robbins \& Judge, 2013). Komitmen organisasional menjadi suatu hal yang penting pada zaman sekarang ini. Ketika sebuah perusahaan sangat sulit mencari karyawan yang memiliki kualifikasi yang sangat baik dalam melakukan pekerjaannya, komitmen organisasional adalah salah satu cara dalam 
menentukan karyawan yang memiliki kualifikasi, loyalitas dan kinerja yang baik. Dengan kata lain, komitmen organisasional dijadikan sebagai hal yang penting dalam menentukan karyawan pada level kinerja didalam suatu perusahaan.

Komitmen organisasional merupakan keterikatan emosional, pengidentifikasian dan keterlibatan karyawan terhadap satu institusi. Manfaat dari komitmen karyawan yang tinggi akan meningkatkan produktivitas produktivitas perusahaan, menurunkan tingkat keluar masuknya karyawan, serta meningkatkan kualitas manajerial perusahaan. Ketika komitmen karyawan terhadap perusahaan sudah terbentuk maka karyawan akan memberikan kinerja yang optimal sehingga tujuan dari perusahaan akan tercapai. Bagi karyawan, memiliki komitmen yang tinggi dapat memberikan keuntungan bagi dirinya sendiri, seperti memperluas kesempatan untuk dipromosikan, menurunkan kemungkinan didemosikan, serta membuat dia semakin berpengalaman dalam bidangnya (Triatna, 2015).

\section{SIMPULAN DAN SARAN}

\section{Simpulan}

a. Persepsi dukungan organisasi, karakteristik pekerjaan dan kepuasan kerja berpengaruh positif dan signifikan terhadap komitmen keorganisasian karyawan baik secara parsial maupun secara simultan.

b. Variabel yang berpengaruh domina terhaap komitmen keorganisasian karyawan adalah variable karakteristik pekerjaan, karena menghasilkan nilai signifikansi yang paling kecil dari variabellain.

\section{Saran}

Dari aspek komitmen organisasi, mengingat semua aspek yang dinilai dikategorikan cukup tinggi, maka perlu adanya upaya untuk mempertahankan dan meningkatkan kembali aspek dalam kaitannya dengan senantiasa teguh berkomitmen dengan bekerja secara optimal.

Diharapkan kedepan perusahaan harus mampu lebih bias memperhartikan kesejahteraan karyawannya, agar karyawa dapat lebih berkomitmen lagi dalam bekerja, serta berkomitmen untuk dapat memajukan perusahaan.

Diharapkan kedepan pihak manajemen perusahaan perlu melakukan evaluasi mengenenai kebebasan karyawan dalam menentukan prosedur dan jadwal pelaksanaan kerja, agar karyawan merasa lebih nyaman dalam melaksanakan pekerjaan.

Diharapkan kedepan pihak manajemen perusahaan perlu melakukan evaluasi mengenai kesesuaian pekerjaan karyawannya dengan keterampilan yang dimiliki. Hal ini dirasa penting, karena semakin sesuainya pekerjaan yang dijalani dengan keterampilan yang dimiliki, akan memberikan rasa nyaman bagi karyawan dalam melaksanakan tugas pokok dan fungsinya.

Penelitian ini perlu di tindak lanjuti lagi untuk melihat faktor apa saja yang dapat mempengaruhi komitmen keorganisasian karyawan. Dimana faktor-faktor tersebut yang dapat mempengaruhi komitmen organisasi adalah faktor personal yang terdiri dari kemampuan dan keahlian, latar belakang dan demografi, dan 2) faktor organisasi yang terdiri dari sumber daya, kepemimpinan, penghargaan, struktur, budaya organisasi dan job design (Simamora dalam Mangkunegara, 2014).

\section{DAFTAR PUSTAKA}

Afzali, A., Motahari, A. A., \& Hatami-Shirkouhi, L. (2014). Investigating the influence of perceived organizational support, psychological empowerment and organizational 
learning on job performance: An empirical investigation. Tehnicki Vjesnik.

Ekayanti, W., Widjajani, S., \& Budiyanto, B. (2019). Pengaruh Karakteristik Personal dan Karakteristik Pekerjaan terhadap Komitmen Organisasional Perawat. Jurnal Maksipreneur: Manajemen, Koperasi, Dan Entrepreneurship. https://doi.org/10.30588/jmp.v8i2.415

Handoko, T. H. (2011). Manajemen Personalia dan Sumber Daya Manusia. Pengantar Manajemen.

Hasibuan, M. S. P. (2011). Manajemen Sumber Daya Manusia. Edisi Revisi Jakarta: Bumi Aksara.

Henry, S. (2003). Manajemen Sumber Daya Manusia In Manajemen Sumber Daya Manusia. In Edisi Revisi Jakarta: Bumi Aksara.

Islam, T., Ahmed, I., \& Ahmad, U. N. B. U. (2015). The influence of organizational learning culture and perceived organizational support on employees' affective commitment and turnover intention. Nankai Business Review International. https://doi.org/10.1108/NBRI-01-2015-0002

Kreitner, R., \& Kinicki, A. (2014). Perilaku Organisasi Organizational Behavior. In 1.

Luthans, F. (2006). Perilaku Organisasi, Edisi Sepuluh. PT. Andi: Yogyakarta.

Martono, S., Dirgantoro, G.S., Ranihusna, D., dan Wiratno, V. (2017). Pengaruh Karakteristik Pekerjaan, Budaya Organisasi dan Kepuasan Kerja pada Komitmen Organisasional. Jurnal Studi Manajemen Organisasi, Volume 2, No. 14.

Mathis, R. L., \& Jackson, J. H. (2012). Manajemen Sumber Daya Manusia. In Manajemen Sumber Daya Manusia.

Nazir, O., \& Islam, J. U. (2017). Enhancing organizational commitment and employee performance through employee engagement: An empirical check. South Asian Journal of Business Studies. https://doi.org/10.1108/SAJBS-04-2016-0036

Novieka, \& Prasetya, A. (2018). Pengaruh Komunikasi Organisasi Terhadap Kepuasan Kerja dan Komitmen Organisasional (Studi pada Karyawan PT PLN Persero Area Pasuruan). Jurnal Administrasi Bisnis (JAB).

Panggabean, M.S. (2011). Manajemen Sumber Daya Manusia. Jakarta : Penerbit Ghalia Indonesia.

Pratama, E.W., Musadieq, M.A., dan Mayowan, Y. (2016). Pengaruh Kompensasi dan kepuasan Kerja Terhadap Komitmen Organisasional (Studi pada Karyawan KSP Sumber Dana Mandiri Gresik). Jurnal Administrasi Bisnis (JAB), Vol. 34, No. 1.

Purnami, P. R. (2017). Pengaruh Kompensasi Dan Persepsi Dukungan Organisasi Terhadap Komitmen Organisasi Dan Kinerja Karyawanrumah Sakit Balimed Karangasem. Jurnal Ekonomi \& Bisnis. https://doi.org/10.22225/JJ.4.1.226.95-107

Purwanto, B. H., \& Soliha, E. (2017). Pengaruh karakteristik pekerjaan dan kompetensi terhadap kinerja melalui komitmen organisasional. Jurnal Manajemen. https://doi.org/10.24912/jm.v21i2.233

Ramadhani, A. F. (2018). Pengaruh Persepsi Dukungan Organisasional terhadap Komitmen Organisasional dan Kinerja Karyawan dengan Keterikatan Karyawan sebagai Variabel Mediasi pada SMK SMTI Yogyakarta. Journal Portal.

Rhoades, L., \& Eisenberger, R. (2002). Perceived organizational support: A review of the literature. Journal of Applied Psychology. https://doi.org/10.1037/00219010.87.4.698

rivai dan sagala. (2011). Manajemen sumber daya manusiauntuk perusahaan dari teori ke praktek. Rekrutmen.

Robbins, S. P., \& Judge, T. A. (2013). Organizational Behavior 15th Edition. In The 
Curated Reference Collection in Neuroscience and Biobehavioral Psychology.

Sancaya, I. G. N. W. (2019). Pengaruh Karakteristik Personal Dan Karakteristik Pekerjaan

Terhadap Komitmen Organisasi Karyawan Pengerajin Kain Tenun Endek Di Pelangi Traditional Weaving Sidemen Tahun 2016. Jurnal Pendidikan Ekonomi Undiksha. https://doi.org/10.23887/jjpe.v10i2.20092

Sharma, J., \& Dhar, R. L. (2016). Factors influencing job performance of nursing staff: Mediating role of affective commitment. Personnel Review. https://doi.org/10.1108/PR-01-2014-0007

Triatna, C. (2015). Perilaku Organisasi dalam Pendidikan. Bandung: Remaja Rosdakarya Offset. 